\title{
Solidarity as a Principle of International Law: Its Application in Consensual Intervention
}

Themistoklis Tzimas*

DOI: $10.21827 / 5 b f 3 e a 340 \mathrm{e} 002$

\section{Keywords \\ SOLIDARITY; CONSENSUAL INTERVENTION; ARMED CONFLICTS}

\begin{abstract}
The article analyses solidarity as a principle of international law, in relation to consensual intervention. The main point of the article is that solidarity constitutes a fundamental principle of international law which lies at the center of the collective security system. This is why solidarity, in the framework of international law must comply with the ultimate goal of the preservation of international peace and security. In such a framework, consensual intervention is assessed from the perspective both of the inviting as well as of the intervening part, on the basis of several criteria, including the level of actual control on the ground, the compliance with international and domestic law, the scope of the consent and the means of implementation of this scope. In cases of contested domestic authority, a larger variety of criteria need to be taken into account. It is proposed that solidarity can offer a balanced approach, between State-centered and human security or in other words between solidarity among States and solidarity towards the people.
\end{abstract}

\section{Introduction}

Recent years have 'witnessed' a rise both in the invoking of consent in relation to assistance or intervention in the course of internal conflicts, as well as in the latter form of conflicts. From the war in Eastern Ukraine to the 'forgotten war' of Yemen and the unprecedented human catastrophe ${ }^{1}$ - among other cases - consent has become a point of reference in the political and legal debate. Even more heated is the debate about the provision of consent in States of contested authority. In the current article, the issue of consensual intervention is approached from the perspective of the principle of solidarity within international law.

The article distinguishes between solidarity in moral terms and solidarity at the legal level, where it is engulfed into the wider goals of the legal system. This is why solidarity, in the framework of international law must comply with the ultimate goal of the preservation of international peace and security.

Themistoklis Tzimas is a post doc researcher in the University of Macedonia, in Thessaloniki, Greece. He conducts research in issues of state sovereignty and law and technology.

Amnesty International, Yemen The Forgotten War, September 2015, at <www.amnesty.org/ en/latest/news/2015/09/yemen-the-forgotten-war/> (accessed 28 November 2018); World Health Organization, Number of suspected cholera cases reaches 100.000 in Yemen, 8 June 2017, at $<$ www.who.int/mediacentre/news/releases/2017/suspected-cholera-yemen/en/> (accessed 28 November 2018); BBC News, UN: World facing greatest humanitarian crisis since 1945, 11 March 2017, at <https://www.bbc.com/news/world-africa-39238808> (accessed 7 January 2019); EJIL: Talk!, Vermeer, T, The Jus ad Bellum and the Airstrikes in Yemen: Double Standards for Decamping Presidents?, 30 April 2015, at <https://www.ejiltalk.org/the-jus-ad-bellum-and-the-airstrikes-in-yemen-double-standards-fordecamping-presidents $/>$ (accessed 28 November 2018). 
Therefore, acts supposedly of solidarity, among States must be carefully assessed under the collective security system imperatives. Such is the case of consensual intervention. Regarding States of limited sovereignty, ${ }^{2}$ the invitation of a government for intervention and the subsequent positive response by another State must be put under the scrutiny of the examination of government lawfulness, of the rights even of a lawful government, in the course of an internal conflict and of the obligation to meet the standards of solidarity towards both States and people.

\section{The concept of solidarity in - international - law}

A. Solidarity as an ethical-political context and its presence in legal systems

Solidarity has been approached through some numerous perspectives, with many of them originating from interpretations of the human condition and subsequent ethic-political imperatives. It prerequisites bonds on the basis of common characteristics which identify a community as such, tending subsequently towards 'a commitment to some kind of mutual aid or support', ${ }^{3}$ which might escalate from the most minimalistic and archaic unit of the family, to that of nation, class or even to a universalistic version of solidarity, encompassing all of mankind. ${ }^{4}$

While the Christian, ecumenic idea of brotherhood - with its strong, even subconscious, influence even until today - as well as the Aristotelian understanding of the human nature advocate a more or less spontaneous human tendency towards solidarity, in the sense either of caring and love for each other, ${ }^{5}$ or of the need for social coexistence, solidarity is also endorsed as a principle in specific political and legal frameworks. ${ }^{6}$

The former depicts a moral and in such a sense a mainly horizontal conception of solidarity, on the grounds, more or less of an intuitive and spontaneous human tendency; the latter displays a hierarchical, vertical structure, which in the framework of a legal

Risse, T, "Governance Under Limited Sovereignty", in Finnemore, M and Goldstein, J, eds, Back to Basics: Rethinking Power in the Contemporary World. Essays in Honor of Stephen D. Krasner, (2010), 5, as Thomas Risse comments 'while areas of limited statehood belong to internationally recognized states (even Somalia still commands international sovereignty), it is their domestic sovereignty which is severely circumscribed. In other words, areas of limited statehood concern those parts of a country in which central authorities (governments) lack the ability to implement and enforce rules and decisions and/or in which the legitimate monopoly over the means of violence is lacking, at least temporarily. Areas of limited statehood can be parts of the territory (e.g. provinces far away from the national capital), but they can also be policy areas (e.g. the inability to implement and enforce environmental laws). In this understanding, areas of limited statehood are not confined to fragile, failing, or failed states the latter having completely lost their domestic sovereignty.'; Borzel, T and Risse, T, "Dysfunctional Institutions, Social Trust, and Governance in Areas of Limited Statehood", (2015), 67, SFB Governance, Working Paper, at <http://www.sfb-governance.de/publikationen/sfb-700-working_papers/wp67/SFBGovernance-Working-Paper-67.pdf> (accessed 22 June 2016). In this sense, ALS's constitute part of a wider category of 'failures' or 'ellipsis' of governance on behalf of state authorities in parts of the territory or fields of authority, which schematically can be classified as 'dysfunctional state institutions.

3 Llewelyn-Davies, M, "Two Contexts of Solidarity among Pastoral Maasai Women", in Caplan, P and Bujra, JM, eds, Women United, Women Divided: Cross-Cultural Perspectives on Female Solidarity (Tavistock 1978), 206.

4 Bayretz, K, "Four uses of 'Solidarity", in Bayertz, K, ed, Solidarity (Springer 1999), 5; Brunkhorst, H, Solidarity: From Civic Friendship to a Global Legal Community, (MIT Press 2005), at IX, 64.

5 Brunkhorst, H, Solidarity: From Civic Friendship to a Global Legal Community, (MIT Press 2005); Dobrzański, D, "The Principle of Solidarity", in Dobrzański, D ed, The Idea of Solidarity: Philosophical and Social Contexts, (The Council for Research in Values and Philosophy 2011), 10.

6 This latter concept is also closer to the Ancient Greek approach which identified specific virtues in the framework of 'polis' - i.e. of the city - making them essentially political virtues or virtues of the righteous citizen. 
system necessitates or rewards specific acts as acts of solidarity. In other words, solidarity is welcomed as a means for an end and not as a self-evidently, 'righteous' human tendency. ${ }^{7}$

In such a context, solidarity is depicted as not a solely or mainly spontaneous but also as a sophisticated and rationally orchestrated praxis, which is eventually shaped as a legal principle. ${ }^{8}$

\section{B. Solidarity as a principle of international law}

As the previous horizontal/vertical distinction indicates, solidarity constitutes a legal principle as well, imposing the abstention or fulfilment of certain acts. A precise, 'official' definition of solidarity as a legal concept is absent and not always necessary. Elements from the moral as well as the normative level must be combined in order to have an accurate description. ${ }^{9}$

A working description would refer to the help among actors in furtherance of common goal, values or avoidance of common danger. In the international community and therefore in international law, the provision of such 'help' under the aforementioned circumstances constitutes fundamental, constitutional principle, given that although it is not mentioned per se, it transcends and signifies some of the fundamental pillars of the international legal order, as the latter is drawn in the UN Charter. ${ }^{10}$

The most profound among them is the collective security system, concerning both the (inter) State, as well as the human security pillar.

Regarding the inter-State level, the exceptional and for limited time lawfulness of State use of force - until the UN Security Council deals with the situation-as well as the

It has been also described as the distinction between solidarity from below and solidarity from above; Cook, K, "Solidarity as a basis for human rights: Part 1: legal principle or mere aspiration?", 5 European Human Rights Law Review (2012), 504, 505; Regarding its impact as an interpretative tool of international law, see: Wolfrum, R and Kojima, C, eds, Solidarity: A Structural Principle of International Law (Max-Planck Institut fur auslandisches offentliches Recht and Volkerrecht, Springer 2009), 45; The horizontal/vertical distinction can be found within the international legal framework too, albeit with a different meaning, as a distinction between solidarity among States and solidarity among States and populations. Boisson de Chazournes, L, "Responsibility to Protect: Reflecting Solidarity?", in Wolfrum, R., Kojima C., eds, Solidarity: a structural principle of international law, (Springer 2010), 102.

8 Dobrzański, supra nt 5, 12.

9 Hayward, JE, "Solidarity: The Social History of an Idea in Nineteenth Century France", 4 International Review of Social History (1956), 261-284; Hayward, JE, "Leon Bourgeois and Solidarism", 6 International Review of Social History (1961), 19-48; Durkheim, E, Moral Education, (Free Press 1986); In such a sense for example, Hayward describes a three- stage process starting from the French revolution with mystification of the concept of solidarity, mainly signifying a legal obligation, then becoming more of a political idea during the period between 1849 and 1895 and in the third phase, from 1896 onwards, when it emerged as a 'dogmatic credo', promoting social reforms and entering the diplomatic language as well; Dworkin, R, Taking Rights Seriously, (Harvard University Press, 1978), 22, 24-25; Such a description seems to fit - up to some extent - with Dworkin's description of principles as 'a requirement of justice or fairness or some other dimension of morality.' In addition, again according to the Dworkinian perspective, principles are different from rules in that they serve as more general guidelines; Alexy, $\mathrm{R}, A$ Theory of Constitutional Rights, (Oxford University Press 2002), 47; As Alexy frames it 'principles are norms which require that something be realised to the greatest extent possible given the legal and factual possibilities. Principles are optimisation requirements, characterised by the fact that they can be satisfied to varying degrees, and that the appropriate degree of satisfaction depends not only on what is factually possible but also on what is legally possible.'

10 For analysis of the UN Charter as a constitutional text, indicatively, see: Franck, T, "Is the U.N. Charter a Constitution?", in Frowein, JA, ed, Negotiating For Peace: Liber Amicorum Tono Eitel, (Springer-Verlag 2003), 95; Schwindt, CJ, "Interpreting the United Nations Charter: From Treaty to World Constitution", 6 U. C. Davis Journal of International Law \& Policy (2000) 194, 206. 
obligation of all States to confront aggression, illegal use of force and not to recognise as lawful the results of violations of jus cogens norms, regardless of whether they are victims of such acts or not, prerequisites the central place of solidarity in international law.

The innovation of the collective security system is the fact that it imposes a centrally organised and regulated system of response to threats against international peace and security, which is entrusted not only on the affected States but on the whole of the international community and its member-States. ${ }^{11}$

In other words, because solidarity is so crucial for international law and for the international community in order for them to retain their consistency and viability, on the basis of aspirations which unite mankind and in the face of dangers which threaten it, a collective, ecumenical response is necessary, in furtherance of which inter-State solidarity is considered as a fundamental principle. ${ }^{12}$ Even further, States' perceptions of their security are supposed to be incorporated into the wider, collective, security system. ${ }^{13}$

In addition, the collective security system is in principle designed and certainly during last decades has come to endorse the principle of solidarity towards non-State actors too. In a number of cases, events of domestic nature of States were perceived by the UNSC as threats against international peace and security, exactly in the name of collective security and of solidarity towards peoples or groups of people. ${ }^{14}$

Mass violations of human rights, colonial and racist regimes, terrorism, failed States, the commitment of internationally prohibited crimes such as genocide, war crimes, crimes against humanity and ethnic cleansing have all been considered at times as such threats, requiring and necessitating the solidarity of States or of international organisations towards the peoples as well, even at the expense of State interests or contrary to them. ${ }^{15}$

The collective security system emerges thus, as a combination of two pillars - of State - centred and of human security. The inspiration behind both of them, ${ }^{16}$ lies with the principle of solidarity and of collective sharing of responsibility as well as of burden. ${ }^{17}$ It is

11 White, ND, "On The Brink Of Lawlessness: The State Of Collective Security Law" 13 Indiana International \& Comparative Law Review (2002) 237, 237; Claude Jr, IL, American Approaches To World Affairs, (University Press of America 1986), 51; Morgenthau, H, Politics Among Nations, (Peter Labella and John M Morriss 1949), 232.

12 Anderson, K, "United Nations Collective Security and The United States Security Guarantee In An Age Of Rising Multipolarity: The Security Council As The Talking Shop Of The Nations", 10 Chicago Journal of International Law (200), 55, 59; Wolfers, A, Discord And Collaboration, (The John Hopkins Press 1962), 168.

13 Wolfers, supra nt $12,170$.

14 Iraq, Somalia, Haiti, Rwanda, DR Congo are some of the equivalent cases; Le Mon, J and Taylor, RS, "Security Council Action in the Name of Human Rights: From Rhodesia to the Congo" 10(2) UC Davis Journal of International Law (2004) 197, 199; Arnison, ND, "International Law and Non- Intervention, When Do Humanitarian Concerns Supersede Sovereignty?" 17 Sum Fletcher F. World AFF (2003) 199, 203.

15 Reisman, TWM, "Acting Before Victims Become Victims: Preventing and Arresting Mass Murder" 40 Case W. Res. J. Int'l L. (2008) 57, 78; Duffy, H, The 'War On Terror' And The Framework Of International Law, (Cambridge University Press 2005), 178 and 184; Shestack, JJ, "Globalization of Human Rights Law", 21 Fordham International Law Journal (1997-1998), 558, 566; Stern, B, "What Exactly Is the Job of International Institutions?" 90 American Society of International Law Proceedings (1996), 585, at 587.

16 Claude, IL Jr, American Approaches To World Affairs (University Press of America 1986), 51; White, ND, "On The Brink Of Lawlessness: The State Of Collective Security Law", 13 Indiana International \& Comparative Law Review (2002), 237, 237; Fowler, MR, "Collective Security And The Fighting In The Balkans", 30 Northern Kentucky Law Review (2003), 299; Morgenthau, H, Politics Among Nations, (Peter Labella and John m. Morriss 1949), 232.

17 Wolfers, A, Discord And Collaboration (The John Hopkins Press 1962), 168; Article 43, United Nations, Charter of the United Nations (1945) 1 UNTS XVI (UN Charter): 'All Members of the United Nations, in 
the acknowledgment of the importance of the principle of solidarity, combined with the history and the realities of the international community, that led to the foundation of the UN and of the collective security system. ${ }^{18}$

In this framework, article 54 of the ILC final articles on State Responsibility explicitly suggests that 'injured' States, as defined in article 42, are not the only States entitled to invoke the responsibility of a State for an internationally wrongful act under chapter I of this Part. Article 48 allows such invocation by any State, in the case of the breach of an obligation to the international community as a whole, or by any member of a group of States, in the case of other obligations established for the protection of the collective interest of the group. By virtue of article 48, paragraph 2, such States may also demand cessation and performance in the interests of the beneficiaries of the obligation breached. ${ }^{19}$ It is a provision whose implementation lies with the initiative of individual States too ${ }^{20}$ provided that they are 'lawful measures', meaning within the framework of international law.

The centrality of solidarity in and through the collective security system, as well as the reference of it to all actors and legal subjects - States and non-State alike ${ }^{21}$ determines the emergence of a variety of other manifestations of solidarity in international law, which re- ascertain that the latter constitutes a principle of the international legal order, expanding the field of threats in the face of which solidarity can be invoked, ${ }^{22}$ as well as the depth of it, regarding the actors towards whom solidarity is directed, exceeding inter-State solidarity in favour of solidarity towards the people too.

Responsibility to Protect - R2P - as a 'concept-in-the-making' both in political and in legal terms indicate a rather 'lato sensu' sense of responsibility, which is indicative of a tendency of the international community to enhance the fortification of already existing legal norms. ${ }^{23}$

order to contribute to the maintenance of international peace and security, undertake to make available to the Security Council, on its call and in accordance with a special agreement or agreements, armed forces, assistance, and facilities, including rites of passage, necessary for the purpose of maintaining international peace and security'; Article 51, UN Charter, is characteristic and definite in its wording by recognising on the one hand, in extremis the potential for collective self-defense, and through that for a type of horizontal act of solidarity, while on the other hand placing a limit on the first type of acts which are the $\mathrm{SC}$ actions on the matter.

18 Reyes, CL, "International Governance Of Domestic National Security Measures: The Forgotten Role Of The World Trade Organization"14 UCLA Journal of International Law and Foreign Affairs (2009), 531, 535536.

19 Article 54, International Law Commission, Draft articles on Responsibility of States for Internationally Wrongful Acts, with commentaries, 2001, A/56/10 (ILC) 137, para 1.

Ibid., para 2.

Boisson de Chazournes, supra nt 7, 94-95.

UN General Assembly, A more secure world: our shared responsibility, Report of the High-level Panel on Threats, Challenges and Change, 2 December 2004, (5 ${ }^{\text {th }}$ session), A/59/565, 11, at $<$ www.un.org/secureworld/report.pdf> (accessed 27 June 2017), (A more secure world); Slaughter, AM, "Security, Solidarity, And Sovereignty: The Grand Themes of UN Reform", 99 American Journal of International Law (2005), 619, 623.

23 Magnuson, W, "The Responsibility to Protect and the Decline of Sovereignty: Free Speech Protection under International Law" 43 Vanderbilt Journal of Transnational Law (2010) 255, 292- 293; UNGA, A more secure world, supra nt 22; Indicative reference regarding the flow of significant texts in the context of R2P can be made to the report of the United Nations Secretary-General's High-Level Panel on Threats, Challenges and Change entitled "A More Secure World: Our Shared Responsibility", as well as the UN Secretary-General report entitled 'In Larger Freedom'; In Larger Freedom: UN Security Council, Towards Development, Security and Human Rights for All, Report of the Secretary-General (2005) A/59/2005, at www.un.org/largerfreedom/contents.htm (accessed 27 June 2017); Kokott, J, States, Sovereign Equality, 
A variety of areas which are critical for the sustainability of the international community endorses fundamentally solidarity: human rights law which is based at large at the universalistic notion of solidarity ${ }^{24}$ environmental law which shares a clear imprint of the principle of solidarity, from the 1972 Stockholm Declaration, to 1992 Rio Declaration ${ }^{25}$ and to Paris Agreement. ${ }^{26}$ In addition, aspects of international economic law too, such as the New International Economic Order - NIEO - and the Charter of Economic Rights and Duties of States are influenced - directly and indirectly - to solidarity as a legal principle. ${ }^{27}$

In such a framework, MacDonald comments that 'Solidarity is first and foremost a principle of cooperation which identifies as the goal of joint and separate State action an outcome that benefits all States or at least does not gravely interfere with the interests of other States... creates a context for meaningful cooperation that goes beyond the concept of a global welfare State; on the legal plane, it reflects and reinforces the broader idea of a world community of interdependent states' ${ }^{28}$ The description is helpful, albeit incomplete

in Max Planck Encyclopedia of Public International Law, paras. 28-29, at www.mpepil.com/sample_article?id=/epil/entries/law-9780199231690-e1113\&recno=26\& (accessed 24 April 2012).

24 Cook, K, "Solidarity as a basis for human rights: Part 2: "practical solidarity"” 6 European Human Rights Law Review (2012), 654, 658; Also see: 'Each State Party to the present Covenant undertakes to take steps, individually and through international assistance and co-operation, especially economic and technical, to the maximum of its available resources, with a view to achieving progressively the full realisation of the rights recognised in the present Covenant by all appropriate means, including particularly the adoption of legislative measures'.

UN General Assembly, International Covenant on Economic, Social and Cultural Rights (1966) 993 UNTS 3 , para 1 (ICESCR).

Other documents in relation to human rights also contain references to solidarity, such as for example: Article 1, Preamble, Universal Declaration of Human Rights, 38; African Commission on Human and People's Rights; African (Banjul) Charter of Human and Peoples' Rights; UN General Assembly Resolution 3201 (S-VI), Declaration on the Establishment of a New International Economic Order, 1 May 1974, (6 ${ }^{\text {th }}$ special session) A/RES/S-6/3201.

25 Chapter I, Declaration of the United Nations Conference on the Human Environment, Report of the United Nations Conference on the Human Environment, 1 January 1973, UN Doc A/CONF.48/14/Rev.1; Volume I, Annex I, Principle 27, Rio Declaration on Environment and Development, Report of the United Nations Conference on Environment and Development, 12 August 1992, UN Doc A/CONF.151/26/Rev.1.

26 Solidarity in international environmental law is demonstrated in three ways: 'in relation to the principle of 'common but differentiated responsibilities' ('CBDR'), which is based on the need for states to cooperate 'in a spirit of global partnership' in order to conserve and protect the Earth's ecosystem...', second '...by way of the flexibility mechanisms, and in particular, the Clean Development Mechanism ('CDM')...' and third '...by the creation of funding initiatives.' Williams, A, "Symposium--Climate Justice and International Environmental Law: Rethinking the North-South Divide', 10 Melbourne Journal of International Law (2009), 493, 505-507.

27 UN General Assembly, Declaration on the Establishment of a New International Economic Order, 1 May 1974, A/RES/S-6/3201; UNGAOR, 6th Specialized Session, Support No 1 (1974) A/9559; Charter of Economic Rights and Duties of States, GA Res 3281 (XXIX), (1974) A/3281; International Law Association, Report of The Sixty-Second Conference held at Seoul, from 24 August to 30 August 1986, 5; The Seoul declaration of the International Law Association, which further elaborated the issue by stating that 'The principle of solidarity reflects the growing interdependence of economic development, the growing recognition that States have to be made responsible for the external effects of their economic policies and the growing awareness that underdevelopment or wrong development of national economies is also harmful to other nations and endangers the maintenance of peace. Without prejudice to more specific duties of cooperation, all States whose economic, monetary and financial policies have a substantial impact on other States should conduct their economic policies in a manner which takes into account the interests of other countries by appropriate procedures of consultation. In the legitimate exercise of their economic sovereignty, they should seek to avoid any measure which causes substantial injury to other states, in particular to the interests of developing States and their peoples'.

28 R. St J. Macdonald, Solidarity in the Practice and Discourse of Public International Law, (1996) 8, Pace 
in the sense that it does not encompass the whole of the actors which participate in the international community and on whose, solidarity applies as a principle.

Different conceptual approaches, argue in favour of the distinction between solidarity and cooperation, as well as of solidarity and collective security identifying in the former a principle which is autonomous and not secondary to another concept. ${ }^{29}$ While this view has the merit of addressing solidarity as an autonomous principle it fails to capture the fact that a principle can transcend other principles and norms while still being autonomous and not of a subordinate nature.

In such a sense the argument of this paper is that solidarity, because it is a fundamental and primary principle of international law is also omnipresent in the collective security system and in a vast area of international law. It has been 'formulated with the intention of changing or confirming, as the case may be, elements of the existing legal order, or if its implementation would have that effect' ${ }^{30}$

Characteristically, the independent expert for human rights on behalf of the human rights commission, Rudi Muhammad Rizki, in his report of 2010, concluded that 'International solidarity is perceived by virtually all respondents as a principle, and by several as a right in international law...International solidarity is seen as a means essential to the international community's pursuit of peace, sustainable development and the eradication of poverty. ${ }^{31}$

As UN, General Assembly - GA - resolution 57/213 provided in one of the few documents where solidarity is explicitly mentioned, it is 'a fundamental value, by virtue of which global challenges must be managed in a way that distributes costs and burdens fairly, in accordance with basic principles of equity and social justice, and ensures that those who suffer or benefit the least receive help from those who benefit the most; ${ }^{32}$ Similarly, the Human Rights Council report on 'Human Rights and International Solidarity' and the 2000 UN Millennium Declaration, referred to solidarity as a principle or value of international law. ${ }^{33}$

In this framework, a more specific manifestation of solidarity is analysed in this article, namely, consensual intervention or intervention by invitation. The following debate encompasses both 'directions' of solidarity: between governments but also towards

International Law Review, 259, 259-260; Keohane, RO, "Sovereignty, Interdependence, and International Institutions", in Miller, LB and Smith, MJ, eds, Ideas \& Ideals: Essays On Politics In Honor of Stanley Hoffmann (Westview 1993), 91 and 92.

29 Boisson de Chazournes, supra nt 7, 97.

30 Cook, supra nt 7, 509; Cheng, B, General Principles of Law as Applied by International Courts and Tribunals, (Cambridge University Press 2006), 7-25.

31 Rizki, RM, Report of the Independent Expert on Human Rights and International Solidarity, 5 July 2010 , $\mathrm{A} / \mathrm{HRC} / 15 / 32$ para 6.8; Not all state or academic opinions on the matter are unanimous though. There are opinions which denounce the existence of a legal principle of solidarity, arguing that it exists solely as a political and moral principle. Dann, P "Solidarity and the Law of Development cooperation" in Wolfrum and Kojima, eds, Solidarity: A Structural Principle of International Law (Max-Planck-Institut fur auslandisches offentliches Recht and Volkerrecht, Springer 2009); Other approaches have been proposed as well, suggesting that solidarity is indeed a legal principle but without adding new obligations, while other approaches insist on a re-distributive consequence of solidarity as a legal principle in favour of lessdeveloped states; Williams, A, "Symposium--Climate Justice and International Environmental Law: Rethinking the North-South Divide", 10 Melbourne Journal of International Law (2009), 493, 503.

32 UN General Assembly, Promotion of a democratic and equitable international order, 25 February 2003, (57th plenary meeting) A/RES/57/213.

33 Human Rights Commission, Human rights and international solidarity (2009) A/HRC/12/L.20, paras 1416; UNGA, Resolution 55/2. United Nations Millennium Declaration, 18 September 2000, (55 ${ }^{\text {th }}$ plenary meeting) A/RES/55/2, para 6. 
the people.

\section{Intervention by Invitation and Its Limits}

\section{A. The Limits of the Right of a Legitimate Government to Consensual Intervention} The concept of intervention by invitation or with consent, has been proven, in practice, to be one of the most complicated, implicating issues of government legitimacy (from different perspectives) as well as collective security. ${ }^{34}$

Traditionally, it is widely accepted that an invitation by the recognised government of a State, 35 which effectively controls the territory and the population, constitutes a legitimate basis for intervention, ${ }^{36}$ provided the consent to intervention is genuine. ${ }^{37}$

The origins of this approach can be identified in a combination of mainstream concepts about sovereignty, approaches to international law as a legal system built on State consent and the provisions of the UN Charter regarding the equal sovereignty of all States. On the basis of such an understanding of sovereignty, the foundation of which is that the sovereign is the ultimate and sole superior over the territory and the population in legal and political terms ${ }^{38}$, it is widely accepted that the government of a State possesses the authority to opt out of the general prohibition on the use of force, which is foreseen in the Charter, when providing its consent for an intervention in its territory.

The invitation of intervention is perceived as a bilateral agreement between the inviting, or consenting, part and the intervening part, which suspends the normal code of conduct and rules regulating their relationship regarding the use of force. ${ }^{39}$ After all, force is not used against the territorial integrity or the political independence of the State, but in furtherance of them, despite literally taking place in the territory of the State.

Because of that, the 'Use of Force Committee of the International Law Association' characterised consent as an 'additional lawful basis for a state's armed forces to enter and/or be stationed on the territory of another state...' It also suggested that consent is not 'an exception to the prohibition of the use of force. The exceptions of Security Council authorisation and self-defence (as discussed above) remain a violation of State sovereignty,

Falk, RA, "Introduction", in Falk, RA, ed, The International Law of Civil Wars (John Hopkins Press 1971), 18; The area under examination is that of internal armed conflicts, in the sense of 'sustained, large-scale violence between two or more factions seeking to challenge, in whole or in part, the maintenance of governmental authority in a particular state.'; Millerson, R, "Intervention by Invitation", in Damrosch, $\mathrm{L}$ and Scheffer, D, eds, Law and Force in the New International Order (Westview Press 1991), 127,128-29; Henkin, L, "The Invasion of Panama Under International Law: A Gross Violation", 29 Columbia Journal of Transnational Law (1991), 293; Reisman, WM, "Humanitarian Intervention and Fledgling Democracies", 18 Fordham International Law Journal 794, (1995), 800.

35 Abass, A, "Consent Precluding State Responsibility: A Critical Analysis", 53 International and Comparative Law Quarterly (2004), 211, 223-224; The government is supposed to bear and exercise the sovereignty of the state and therefore express its will.

36 Whippman, D, "Military Intervention, Regional Organizations and Host-State Consent", 7 Duke Journal of International \& Comparative Law, (1996), 209, 209.

37 International Law Commission, Ago, R, Eighth Report on State Responsibility, (1979) A/CN.4/318, para $3,35-36$.

38 Worth, JR, "Globalization and The Myth of Absolute National Sovereignty: Reconsidering The 'UNSIGNING' Of The Rome Statute And The Legacy Of Senator Bricker", 79 Indiana Law Journal (2004) 245, 258; Kwiecie, R, "Does the State Still Matter? Sovereignty, Legitimacy and International Law", 32 Polish Yearbook of International Law (2012), 45, 57, 60; Frohnen, BP, "A Problem of Power: The Impact of Modern Sovereignty on The Rule of Law in Comparative and Historical Perspective", 20 Transnational Law \& Contemporary Problems (2012), 599, 600; Permanent Court of International Justice (PCIJ), The case of the S.S. "Lotus" (Francev Turkey), PCIJ Series A no 10, ICGJ 248, 18, 7 September 1927.

39 Ago, R, supra nt 37, paras 31-32. 
but are excused violations. On the other hand, a State's use of force on the territory of another State upon its consent involves no violation of State sovereignty ab initio.' ${ }^{40}$

The same view was adopted by the International Court of Justice in the famous Nicaragua Case, ${ }^{41}$ as well as in the DRC v Uganda case, provided the consent was valid. ${ }^{42}$ The Draft Articles on State Responsibility also provide in article 20, that: 'Valid consent by a State to the commission of a given act by another State precludes the wrongfulness of that act in relation to the former State to the extent that the act remains within the limits of that consent.' 43

Implicit, albeit strong evidence for the prevalence of this approach can be found in two UN Resolutions; 3314 and 387 respectively. Article 3, para. e, of resolution 3314 defines aggression as - among other things: 'The use of armed forces of one State which are within the territory of another State with the agreement of the receiving State, in contravention of the conditions provided for in the agreement or any extension of their presence in such territory beyond the termination of the agreement; ${ }^{44}$ Indirectly but profoundly it can be concluded that within the framework of the agreement of the hosting State, the military activities are legitimate. The Security Council, in its 387 resolution, also reiterated the 'inherent' right of every State to '....request assistance from any other State or Group of States. ${ }^{45}$ Combining the aforementioned positions, the lawfulness of consensual intervention has come to be considered by several analysts as axiomatic. ${ }^{46}$

Consensual intervention is implicitly presented as a manifestation of inter-State solidarity, which therefore complies with the inherent admissions of the collective security system and thus retains its lawfulness.

This is not an uncontested approach, of course. The core of the theoretical argument about non-interventionism, in spite of consent, is that since a government needs to invite a foreign intervention in order to consolidate its authority, its position as sovereign is already compromised and therefore a foreign intervention will determine what is, and what should be, essentially a domestic rivalry for the determination of the polity and the socio-economic model of a country; therefore, a violation of self-determination and sovereignty. 47

In addition, it is argued that intervention even by consent could internationalise the

40 International Law Association, Washington Conference, Use of Force, Report on Aggression and the Use of Force, (2014), 13.

41 International Court of Justice (ICJ), Case Concerning Military and Paramilitary Activities in and Against Nicaragua (Nicaragua v United States of America) (Merits, Judgment) [1986] ICJ Rep 14, para 126.

42 McGuinness, M, Case Concerning Armed Activities on the Territory of the Congo: The ICJ Finds Uganda Acted Unlawfully and Orders Reparations, (2006), 10(1), ASIL Insights.

43 Article 20, International Law Commission, Draft Articles on Responsibility of States for Internationally Wrongful Acts, 53rd Session, April 23 - June 1, July 2 - August 10, 2001; A criticism to this argumentation though is that it lacks precision given that the term prohibited intervention is not a clarified enough term. Therefore, the preclusion of the wrongfulness of a loosely defined act becomes problematic in the first place.

44 UN General Assembly Resolution, Definition of Aggression, 14 December $1974,\left(29^{\text {th }}\right.$ plenary meeting), A/RES/29/3314, Article 3(e).

45 UN Security Council, Angola- South Africa, 31 March 1976, (1900 ${ }^{\text {th }}$ meeting) S/RES/387.

46 Gray, C, The Use of Force in International Law, (Oxford University Press 2008), 85.

Schmitt, M, Drone Attacks under the Jus as Bellum and Jus in Bello: Clearing the "Fog of Law", (2010) 13, Yearbook of International Humanitarian Law, 311, 315.

47 Lauterpacht, H, Recognition in International Law, (Cambridge University Press 1947), 93-94, 233-234; Byrne, M, "Consent and the Use of Force: an examination of "intervention by invitation" as a basis of US drone strikes in Pakistan, Somalia and Yemen" 3(1) Journal on the Use of Force and International Law (2016) 97, 100. 
conflict therefore it could endanger international peace and security. ${ }^{48}$

Non-interventionism, when projected onto the debate about solidarity implies that inter-State solidarity can be antagonistic with solidarity towards the people of that same State, since or when it suppresses their aforementioned self-determination right. ${ }^{49}$ In the comparison or potential antithesis between the two aspects of solidarity, the latter is perceived as morally prevalent in the sense that the State and its government are supposed to be means for the welfare of the people and not vice-versa. Therefore, inter-State solidarity becomes subordinate to solidarity towards the people.

A number of important scholars endorsed non-interventionism, in the framework of de-colonisation, advocating non-interventionism in furtherance of a right to revolution and internal self-determination. ${ }^{50}$ Intervention under consent is in this sense approached as a violation of article 2(4) of the UN Charter. ${ }^{51}$

From such a perspective, in 1975 the Institut De Droit International - IDI - adopted the Principle of Non-Intervention in Civil Wars, according to which, in any case of internal conflict, no intervention should take place. ${ }^{52}$ Although that was not a complete prohibition of intervention, it extended at the vast area of internal conflicts.

It must be mentioned however, that there is not a unanimous understanding on whether the IDI resolution constituted 'lex lata' or at least a 'persuasive interpretation of the general rule against nonintervention' or 'de lege ferenda'. ${ }^{53}$ However, the attitude which was adopted in the 2009 report seems closer to the latter position, given that it recognises that there are conflicting and opposing views in relation to the issue of nonintervention. ${ }^{54}$

This position was partially amended in 201155 by foreseeing some exemptions to non-interventionism: de-colonisation wars, wars in the course of which genocidal acts or gross violations of human rights take place, civil riots or conflicts below the threshold of

48 Wedgwood, R, "Commentary on Intervention", in Damrosch, LF and Scheffer, DJ, eds, Law and Force in the New International Order (Westview Press 1991), 135.

49 Here can be identified the other interpretation of the vertical/horizontal dimension of solidarity, considering the vertical dimension as inter-State and the horizontal, as directed towards the people. A more accurate description, without making much difference regarding the actual meaning of the terms would be the one differentiating between solidarity among state governments- in this sense horizontal and solidarity between States or international organisations and people - a diagonal aspect of solidarity.

50 Wright, Q, The Role of International Law in the Elimination of War, (Manchester University Press, Manchester, 1961), 61; Brownlie, I, International Law and the Use of Force by States, (Clarendon Press, 1963), 327; Norton Moore, J, "Legal Standards for Intervention in Internal Conflicts", 13 Georgia Journal of International and Comparative Law (1983) 191, 196; Schachter, O, "International Law: The Right of States to Use Armed Force", 82 Michigan Law Review (1984) 1620, 1641; Gray, CFC, International Law and the Use of Force, (Oxford University Press 2008), 81; Max Planck Institute, REPORT: Independent International Fact-Finding Mission on the Conflict in Georgia, Report Vo. II, September 2009, at $<$ http://www.mpil.de/files/pdf4/IIFFMCG_Volume_II1.pdf> (accessed 28 November 2018), 278.

51 Schachter, O, "The Right of States to Use Armed Force" 82(5/6) Michigan Law Review (1984) 1620, 1641.

52 Schindler, D, Institut De Droit International, The Principle of Non-Intervention in Civil Wars, Eighth Commission, Article 2(1), 14 August 1975, at <http://www.idi-iil.org/app/uploads/2017/ 06/1975_wies_03_en.pdf> (accessed 28 November 2018); Third States shall refrain from giving assistance to parties to a civil war which is being fought in the territory of another State.

53 Schachter, O, "International Law: The Right of States to Use Armed Forces" 82, Michigan Law Review (1984) 1620, 1620-1646; Hafner, G, Present Problems of the Use of Force in International Law, (2009), 73, Annuaire de l'Institut de droit international- Session de Naples, $10^{\text {th }}$ Commission, 303, at <http://www.idiiil.org/app/uploads/2017/06/Hafner.pdf> (accessed 21 January 2019).

$54 \quad$ Hafner, supra nt 53, 304.

55 Lieblich, E, International Law and Civil Wars: Intervention and Consent (Routledge 2013), 135. 
non-international armed conflicts and terrorism. ${ }^{56}$

However, it is difficult both from an historical and empirical, as well as from a normative perspective to embrace an absolute prohibition of consensual intervention or even a reversal of the right - in principle - of a State government to consent to intervention. From the Spanish Civil War experience and the failure of the democratic States to provide valuable help to the legitimate government, to the genocide in Rwanda and the current concerns about non-State actors, a solid and general commitment to a 'negative equality' principle and to non-interventionism could seriously undermine international legal norms and collective security.

The complete nonintervention thesis, despite its significance is also influenced by the political realities of each era - such as by the Vietnam war ${ }^{57}$ - and although it might fit in with them, its potential generalisation could and would have undesirable effects in terms of the international legal order.

In addition, a general prohibition of the right of the lawful government to consent would undermine the foundations of international legal order, diminishing State sovereignty, which lies out of the UN Charter context and of the opinio juris of most international actors, States and non-State actors alike. Eventually, it would lead to a situation if imbalance between solidarity towards the people and solidarity among States.

This is why views which attempt to reach a balance between the lawfulness of consensual intervention and the complete noninterventionism emerge. Some of them distinguish between 'de lege lata' and 'de lege ferenda', while others accept the lawfulness of consensual intervention but pay more attention to the legitimacy of the government providing the consent. 58

In general, however, it is reasonable to accept the right of a recognised government State to consent to an intervention in principle but also to question whether it may exercise this right unconditionally or not. The answer to this question prerequisites the answer to a preliminary question: whether sovereignty is legally unlimited or not.

Traditionally, sovereignty is perceived as legally unlimited and unbounded by any other State or authority. This perception has passed into the icon of international law and of the international community as founded on the (inter-) State will and sovereignty. ${ }^{59}$

As Professor Greenwood explains, contrary to domestic legal systems: 'There is no 'Code of International Law'. International law has no Parliament and nothing that can really be described as legislation... The result is that international law is made largely on a decentralised basis by the actions of the 192 States which make up the international

\footnotetext{
$56 \quad$ Hafner, supra nt 53, 319-338.

57 Nolte, G, Intervention upon Invitation: Use of Force by Foreign Troops in Internal Conflicts at the Invitation of a Government under International Law, (Springer 1999), 116.

$58 \quad$ Lieblich, supra nt 55, 137;

59 PCIJ, The case of the S.S. "Lotus" (Francev Turkey), 7 September 1927, PCIJ Series A no 10, ICGJ 248, 18; As the Permanent Court of International Justice in the famous "S. S. Lotus" case held: 'International law governs relations between independent States. The rules of law binding upon States therefore emanate from their own free will as expressed in conventions or by usages generally accepted as expressing principles of law and established in order to regulate the relations between these co-existing independent communities or with a view to the achievement of common aims. Restrictions upon the independence of States cannot therefore be presumed'; Worth, JR, "Globalization and The Myth of Absolute National Sovereignty: Reconsidering The "UN-SIGNING" of The Rome Statute and The Legacy Of Senator Bricker" 79 Indiana Law Journal (2004) 245, 258; Kwiecie, R, "Does the State Still Matter? Sovereignty, Legitimacy and International Law" 32 Polish Yearbook of International Law (2012) 45, 57, 60; Frohnen, BP, "A Problem of Power: The Impact of Modern Sovereignty on The Rule of Law in Comparative and Historical Perspective" 20 Transnational Law \& Contemporary Problems (2012) 599, 603.
} 
community.' ${ }^{60}$ Therefore, once the bearer of sovereignty is identified, no, or little, interference in its free will can be acceptable.

However, sovereignty has also been defined as responsibility '...to protect the welfare of its own peoples' and to 'meet its obligations to the wider international community.' ${ }^{1} 1$ Or, as it has been suggested, the international system or community is nowadays a 'tightly woven fabric of international agreements, organisations, and institutions that shape [States'] relations with each other and penetrate deeply into their internal economics and politics', which necessitates a new type of sovereignty based on achieving common goals through working together. ${ }^{62}$

Since the adoption of the UN Charter, State sovereignty is comprehended not as 'limitless' - not even within the domestic sphere - but as limited or restrained because of the participation of the State in the constitutionally formulated international community and therefore by international law. ${ }^{63}$

It is the State's free will that determines its participation in the wider international community. In such a sense, State sovereignty is not restrained in favour of another sovereign - which would deprive it essentially of its sovereignty - but within a legal system which the State itself has accepted and 'internalised'. ${ }^{64}$ State sovereignty emerges as a concept not distinct from that of the international community, but as a concept existing and evolving within the international community, ${ }^{65}$ under the 'international law

60 United Nations Office of Legal Affairs, Greenwood, C, Sources of International Law: An Introduction, 2008, at <http://legal.un.org/avl/pdf/ls/greenwood_outline.pdf> (accessed 28 November 2018).

61 UNGA, A More Secure World, supra nt 23, 22.

62 Chayes, A and Handler Chayes, A, The New Sovereignty: Compliance with International Regulatory Agreements, (Harvard University Press 1995), 26.

63 Fassbender, B, "Sovereignty and Constitutionalism in International Law", in Walker, N, ed, Sovereignty In Transition (Hart Publishing 2003), 131.

64 Rozakis, L, The Concept of Jus Cogens in the Law of Treaties (Amsterdam North-Holland Publications Co 1976) 1; Characteristically, the violation of jus cogens norms is to be confronted by the international community regardless of sovereignty and potential domestic legitimacy.

65 As an idea it is not that different from Aristotelian or Freudian ideas about why the individual needs to (co-) exist in organised societies, in order to enhance its potentials and achieve a more complete form of humanity, despite the restrictions imposed upon him/her because of his/her social life; The change of paradigm regarding sovereignty is, to some extent, a result of the internationalisation of human rights and a 'humanisation' of international law, of the designation of individuals or communities of people not only as objects but also as partially autonomous subjects of international law, who, under specific circumstances, might not be represented by their governments at the international level, as well as of the institutionalisation of the international community through international legal norms of a fundamental and binding nature regardless of States' adherence to such norms or even contrary to domestic legitimacy; I, Cotler, Minister of Justice and Attorney General of Canada, Building a New International Law: What Have We Learned, What Must We Do?, Address to the Magna Carta Foundation (January 12, 2005). Such are the cases of national liberation and self-determination movements. Under some opinions this is also the case of systematic and gross violations of human rights, although such arguments are far from unanimously accepted; Mullerson, R and Scheffer, DJ, "Legal Regulation of the Use of Force", in Damrosch, L, Danilenko, G and R. Mullerson, R, eds, Beyond Confrontation: International Law For The Post-Cold War Era, (University of Michigan Press, 1995), 125-126; Byers, M, Custom, Power and the Power of Rules: International Relations and Customary International Law (Cambridge University Press 1999), 194; Spagnoli, F, "The Globalization of Human Rights Law: Why do Human Rights Need International Law?" 14 Texas Wesleyan Law Review (2008) 317, 325- 326; Conklin, WE, "The Peremptory Norms of The International Community" 23 European Journal of International Law (2012) 837, 838; Crawford, J, The International Law Commission's Articles on State Responsibility: Introduction, Text, and Commentaries (Cambridge University Press 2002), 148-150, 158-160. 
supremacy principle'. ${ }^{66}$

International law, therefore, because of the supremacy principle, is not merely seated upon the domestic legal order, but also rearranges partially the latter, under the imperatives of the collective security system and its goals, which are articulated in the two aspects of inter- State solidarity and of solidarity towards the people.

In addition, the transformation or reinterpretation of sovereignty in accordance with international law means that while State sovereignty has a singular bearer - namely the government of the State - it is not only a privilege, but also a responsibility towards the people of the State, who participate in the international legal order not only indirectly through their States, but also directly, as subjects and objects of international law. ${ }^{67}$

In such a framework, the traditional concept of State sovereignty is transformed 68 in favour of its approach in the wider framework of international law. The argument then, in relation to consensual intervention, is that even if the government of the State is recognised as the legitimate one, its right to consensual intervention is not absolute. Since the government in general needs to comply with international law - or at least with its most fundamental rules - the government privilege and right to invite an intervention follows the limitations that are imposed upon sovereignty by international law, as well. ${ }^{69}$

In the light of this, the scope of intervention, as well as its methods, must be placed under scrutiny. ${ }^{70}$ An intervention that endangers the collective security system, in furtherance of the commission of internationally prohibited crimes - such as genocide, war crimes, crimes against humanity, ethnic cleansing - implicating the commission of mass and grave violations of human rights, aiming at the suppression of self-determination movements ${ }^{71}$ or which is supportive of apartheid and racist regimes would profoundly contradict international legitimacy; such a contradiction cannot be 'healed' by government invitation. Consent in general can be no excuse for neglecting the rights of individuals within the consenting State, who after all are subjects of international law too, or for violating at least fundamental norms of international law. ${ }^{72}$

An invitation on behalf of the government cannot legitimise an intervention in

66 Article 27, Vienna Convention on the Law of Treaties, 23 May 1969: 'A party may not invoke the provisions of its internal law as justification for its failure to perform a treaty'; Teson, F, "Le Peuple, C'est Moi!: The World Court and Human Rights" (1987) 81 American Journal of International Law (1987) $173,175-178$.

67 Le Mon, J and Taylor, RS, "Security Council Action in the Name of Human Rights: From Rhodesia to the Congo" 10(2) UC Davis Journal of International Law (2004) 197, 199; Arnison, ND, "International Law and Non- Intervention, When Do Humanitarian Concerns Supersede Sovereignty?" 17 Sum Fletcher F. World AFF (2003) 199, 203.

68 Boyle, FA, Destroying World Order: U.S. Imperialism in the Middle East before and after September $11^{\text {th }}$ (Clarity Press, 2004), 107.

69 Orford, A, Reading Humanitarian Intervention, Human Rights and the Use of Force in International Law (Cambridge University Press 2003), 4; Scheffer, DJ, "Toward a Modern Doctrine of Humanitarian Intervention" 23 University of Toledo Law Review (1992) 253, 262- 263; Berlin, AH, "Recognition As Sanction: Using International Recognition Of New States To Deter, Punish, And Contain Bad Actors" 31 University of Pennsylvania Journal of International Law (2009) 531, 568-570.

70 Bannelier, $\mathrm{K}$ and Christakis, T, "Under the UN Security Council's Watchful Eyes: Military Intervention by Invitation in the Malian Conflict" 26 Leiden Journal of International Law (2013) 855, 855-874; BannelierChristakis, K, "Military Interventions against ISIL in Iraq, Syria and Libya, and the Legal Basis of Consent" 29 Leiden Journal of International Law (2016) 743, 745.

71 Wilson, HA, International Law And The Use Of Force By National Liberation Movements (Clarendon Press, 1988), 91-136.

72 Deeks, AS, "Consent To The Use Of Force And International Law Supremacy" 54 Harvard International Law Journal (2013) 1, 21-22. 
furtherance of scope and acts, which, if conducted by the government of the State itself, would be illegal under international law. 73

Article 16 of the International Law Commission report of 2005, on 'Responsibility of States for Internationally Wrongful Acts' - which the International Court of Justice, in the Application of the Convention on the Prevention and Punishment of the Crime of Genocide (Bosnia and Herzegovina v Serbia and Montenegro) determined that endorses a principle of customary international law ${ }^{74}$ - is crystal clear on that. ${ }^{75}$ It prerequisites knowledge on behalf of the assisting State of the unlawfulness of its act and for the act to constitute breach of the State's own obligations, ${ }^{76}$ as well as a 'nexus' between the assistance and the internationally wrongful act. ${ }^{77}$

The level of intent constitutes the one critical issue. As Dapo Akande commented 'Art. 16 ....requires knowledge ... [whereas] the ILC's own commentary ... seems to require that assistance be given 'with a view' to, or with the intent of, facilitating the commission of wrongful act.' The commentary of the ILC refers to awareness of the circumstances determining the wrongfulness. ${ }^{78}$

The ICJ in the Bosnian Genocide Case, as well as several analysts advocated the need of being aware of specific illegality, ${ }^{79}$ as well as that ignorance of law is no excuse. ${ }^{80}$ The issue is far from clear, varying from 'almost certainty ${ }^{81}$ to the much lower level or 'recklessness'. ${ }^{82}$

73 Whippman, D, "Military Intervention, Regional Organizations and Host-State Consent" 7 Duke Journal of Comparative \& International Law (1996) 209, 215.

74 ICJ, Application of the Convention on the Prevention and Punishment of the Crime of Genocide (Bosnia and Herzegovina $v$ Serbia and Montenegro), 26 February 2007, 420; ICJ, Application of the Convention on the Prevention and Punishment of the Crime of Genocide (Bosnia and Herzegovina v Serbia and Montenegro), 26 February 2007 (Dissenting Opinion of Judge ad hoc Mahiou), para 124.

75 Article 16, International Law Commission, Responsibility of States for Internationally Wrongful Acts (2001); 'A State which aids or assists another State in the commission of an internationally wrongful act by the latter is internationally responsible for doing so if: (a) that State does so with knowledge of the circumstances of the internationally wrongful act; and (b) the act would be internationally wrongful if committed by that State'.

76 EJIL: Talk!, Akande, D, Chatham House Paper on Aiding and Assisting by States, November 28, 2016, at $<$ www.ejiltalk.org/chatham-house-paper-on-aiding-and-assisting-by-states/> (accessed 28 November 2018).

77 International Law Commission, supra nt 19.

78 Ibid., Article 16, para 4.

79 ICJ, Application of the Convention on the Prevention and Punishment of the Crime of Genocide (Bosnia and Herzegovina $v$ Serbia and Montenegro), 26 February 2007 (Dissenting Opinion of Judge ad hoc Mahiou), para 421; Chatham House, International Law Program, Moynihan, H, REPORT: Aiding and Assisting: Challenges in Armed Conflict and Counterterrorism, Research Paper, 14 November 2016, at $<$ https://www.chathamhouse.org/publication/aiding-and-assisting-challenges-armed-conflict-andcounterterrorism> (accessed 28 November 2018), para 36; Crawford, J, State Responsibility: The General Part (Cambridge University Press 2013), 407; Nolte, G and Aust, HP, "Equivocal Helpers Complicit States, Mixed Messages and International Law" 58 International \& Comparative Law Quarterly (2009) 1, 14.

80 International Law Commission, Crawford, J, "Statement of Special Rapporteur" I Yearbook of the International Law Commission (1999) 69, para 14.

81 Crawford, J, supra nt 79, 408; International Law Commission, Ago, R, 2(II) Yearbook of the International Law Commission (1978) UN Doc A/CN.4/SER.A/1978/Add.1 (Part 2), para 10; Between actual knowledge, and 'constructive' awareness, an intermediary level which has been proposed is that of 'wilful blindness'; Moynihan, supra nt 79, paras 46-49; ICJ, Corfu Channel case (UK v Albania) (Merits) (1949) ICJ Rep 4; The ICJ, in the 'Corfu Channel Case' interpreted and implemented this criterion as 'must have known'.

82 Just Security, Goodman, R, Foreign Gov't Assistance to Trump Administration Policies: What Int'l Law 
Taking into account the magnitude of State force and impact on international relations, the need to balance between State-centered security and interests on the one hand and human security on the other hand - or in other words taking into account the need to balance between solidarity towards States and towards the people - as well as the practical difficulty in identifying the actual intent of a State, the threshold must not be raised too high to be ever met. In this sense, considerable 'recklessness' in the use of State's own force should be considered as enough in order for State's behavior to fall within the Article 16 provisions.

As for the nexus element, it is not absolutely clear if the threshold is placed at the 'significant contribution' level or even to 'minor degree', although the former seems more suitable as a criterion. ${ }^{84}$ The actual determination of the fulfillment or not of this criterion rests of course on the factual analysis on the ground. Again though, the aforementioned criterion of acknowledgment of State's responsibility and of the need to balance between the State-centered and the human-centered aspects of security and solidarity necessitates an intermediary. ${ }^{85}$ Such cases of consensual intervention would endanger international peace and security and distort the collective security system. ${ }^{86}$

Therefore, while governments do possess in principle the right to invite an intervention, this right is not unlimited and cannot contravene their obligations under international law such as those mentioned above. In addition, while governments can legitimately intervene in the framework of inter-State solidarity they cannot bypass their obligation to take into account their responsibility to manifest their solidarity towards the people of other States too, directly.

This latter remark is not simply 'old wine into new bottle'. The reference to solidarity as a criterion for the assessment of the compliance of States with international law, in the framework of consensual intervention, offers a more thorough examination of the limits of State consent, which are placed in relation to the wellbeing of specific objects of interest - States and people - which need to be taken into account when an intervention is sought.

Solidarity constitutes the internal and fundamental, normative criterion - albeit with a strong ethical component within its normativity - which determines if and how consensual intervention will be implemented, in line with the collective security system imperatives. The limit of horizontal, inter-State agreements is international law, as a legal system with solidarity at its foundation, in its very own, vertical, hierarchical framework

Prohibits, 23 November 2016, at <www.justsecurity.org/34835/foreign-govt-assistance-trumpadministration-policies-intl-law-prohibits/> (accessed 28 November 2018).

83 UN, Draft articles on Responsibility of States for Internationally Wrongful Acts (2001), Article 16, paras 5 and10.

84 Moynihan, supra nt 79, para 24; In any case, the level of the Saudi- led coalition involvement in the Yemeni war is more than significant; it is catalyst.

85 A certain approach would be to distinguish in the face of such situations between the actual act of consent provision and the content, the substance of this act; or in other words between the lawfulness of the intervention as such but not of the actions committed in the course of it, when wrongful acts are committed. While such a clear distinction seems and is logical it fails to capture the organic consistency of the provision of consent: an act of consent must not be assessed only procedurally but also teleologically.

86 White, ND, "On The Brink Of Lawlessness: The State Of Collective Security Law" 13 Indiana International \& Comparative Law Review (2002) 237, 237; Fowler, MR, "Collective Security And The Fighting In The Balkans" 30 Northern Kentucky Law Review (2003) 299, 299; Morgenthau, H, Politics Among Nations: The Struggle for Power and Peace (AA Knopf 1948), 232; Wolfers, A Discord And Collaboration (The John Hopkins Press 1962), 168. 
and of course the collective security system, in its holistic interpretation..$^{87}$

\section{B. The Question of the Right to Consensual Intervention in the Face of Contested Authority and Government Legitimacy}

Things become further complicated in cases of contested sovereignty and government legitimacy. The examination of this last issue requires an analysis of government legitimacy in the course of internal conflict in order to identify criteria according to which one can determine when a government, or any other entity, possesses the authority to consent to an intervention.

The question of government legitimacy has been proven highly divisive partially because of the relative ambiguity of international law, 88 but mainly because of the double if not multiple - standards by States, as well as by UN organs, in the face of different cases. ${ }^{89}$

A standard and traditional approach considers as legitimate the government that controls the territory and the population of a State, 90 for a sufficient period of time,, 91 regardless of other issues of internal or international legitimacy. .92

The UN through its organs appears to have favoured such an approach as the case of the seat of China in the UNSC indicated. Then - Secretary General - SG - of the UN, Trygve Lie, had argued that the legitimate representative of China in the UN should be appointed from the communist instead of the nationalist government, ${ }^{93}$ since the primary was the one controlling the territory and the population and was capable of fulfilling China's obligations towards the UN. 94

89 Smith, S, "The Plight Of The Secular Paradigm" 88 Notre Dame Law Review (2013) 1409, 1412-1413.

90 Farer, TJ, "Panama: Beyond the Charter Paradigm" 84 American Journal of International Law (1990) 503, 510-11; Nowrot, K, "The Use of Force to Restore Democracy: International Legal Implications of the ECOWAS Intervention in Sierra Leone" 14(2) American University International Law Review (1998) 321, 388- 389; Takashi, M, "Recognition of States and Governments in International Law: Theory and Practice" 28 Chinese (Taiwan) Yearbook of International Law and Affairs (2010) 64, 64-65; Lloyd, DO, "Succession, Secession, And State Membership In The United Nations" 26 New York University Journal of International Law \& Politics (1994) 761, 761.

91 Beck, D, The Legal Validity of Military Intervention by Invitation of the Government 56 British Yearbook of International Law (1985) 189, 251.

92 Roth, BR, "Governmental Illegitimacy Revisited: 'Pro-Democratic' Armed Intervention in the PostBipolar World" 3 Transnational Law \& Contemporary Problems (1993) 481, 482; Wimmer, H, The State's Monopoly on Legitimate Violence. - Violence in Historyand in Contemporary World Society as Challenges to the State. Paper presented at the Conference "Transformations of Statehood from a European Perspective", January 23-25 2003, Vienna, organized by the Austrian Academy of Sciences. Vidmar, J, "Territorial Integrity and The Law Of Statehood" 44 George Washington International Law Review (2012) 697, 700; Kelsen, H General Theory Of Law And State (Cambridge University Press 1961), 220-221; Similar is Krasner's suggestion. He went on saying that 'Domestic sovereignty does not involve a norm or a rule, but is rather a description of the nature of domestic authority structures and the extent to which they are able to control activities within a State's boundaries. Ideally, authority structures would ensure a society that is peaceful, protects human rights, has a consultative mechanism, and honours a rule of law based on a shared understanding of justice'; Krasner, S, "Sharing Sovereignty. New Institutions for Collapsed and Failed States" 29(2) International Security (2004) 85, 88; Krasner, S, Sovereignty. Organized Hypocrisy (1999, Princeton University Press), 3.

93 Brownlie, I, Principles of Public International Law (Oxford University Press 1998), 91.

94 Downer, J, "Towards A Declaratory School Of Government Recognition" 46 Vanderbilt Journal of Transnational Law 581 (2013) 589-591; However, this approach does not imply that the communist China did not meet the criteria as they are set by the Charter, concerning international law; US Senate, Committee on Foreign Relations, Libya and War Powers, Hearing, S. Hrg. 112 - 189, 28 June 2011, at 
However, the internal, constitutional legitimacy and the compliance with international law have also been proposed as legitimising factors. ${ }^{95}$ It is in this framework, that in cases of contested authority between the government exercising effective control and the legitimate one according to domestic law, when consensual foreign intervention is at stake, Talmon argues in favour of attributing authority for lawful consent to the latter. ${ }^{96}$

D'Aspremont presented a somewhat different distinction ' ... between the legitimacy pertaining to the source of power and the legitimacy related to the exercise of power', with the primary referring to the origin of power, while the latter to its actual implementation; the qualification of a government originates from the legitimacy according to the origin of power, while disqualification refers to its exercise. ${ }^{97}$

In a number of cases, dealing with military coups or with specific types of regimes, which violate the fundamentals of international law the effective control criterion receded in front of internal legitimacy. ${ }^{98}$

<https://www.foreign.senate.gov/download/hearing-transcript-062811> (accessed 21 January 2019); It has been also proposed that States should not officially recognise or deny recognition to other governments and regimes, but simply deal with them. The official US approach is not that different. The legal adviser of the US Department of State suggested that: '[I]nternational law focuses on the question of recognition, and recognition tends to follow facts on the ground, particularly control over territory. As a general rule, we are reluctant to recognise entities that do not control entire countries because then they are responsible for parts of the country that they don't control, and we're reluctant to derecognise leaders who still control parts of the country because then you're absolving them of responsibility in the areas that they do control'.

95 Reisman, WM, "Humanitarian Intervention and Fledgling Democracies" 18 Fordham International Law Journal (1995) 794, 796; This was not a totally novel approach. In 1964, for example, President Julius Nyere of Tanganyika turned to the UK army when he was overthrown by a coup, asking and legitimising an intervention although he was not in control of his country. Similar consensual interventions have taken place by France in its former colonies. In all these cases, the international community did not seem to question the legitimacy of the interventions; Whippman, supra nt 73, 216.

96 Talmon, S, Recognition of Governments in International Law (Clarendon, 1998), 113; Marks, S, "What Has Become of the Emerging Right to Democratic Governance" 22 European Journal of International Law (2011) 507, 511; In the aftermath of the events in Haiti and of the coup against Gorbachev, the school of Manhattan, and in particular, the work of Thomas Franck advocated the recognition of a right to democratic governance, as an ecumenical criterion for government legitimacy; Roth, B, "Popular Sovereignty: The Elusive Norm" 91 American Society International Law Proceedings (1997) 363, 368; Despite its influence in the academic environment and public debate, the general acceptance of such a criterion of legitimacy has been denounced both on political and legal grounds. After all, neither opinio juris leading to a customary rule- nor a universal definition of democracy can be traced; Steiner, $\mathrm{H}$ and Alston, $\mathrm{P}$, International Human Rights in Context: Law, Politics, Morals ( $2^{\text {nd }}$ ed, Oxford University Press 2000), 888; Foreign Affairs, Nathan, A, The Tiananmen Papers, 1 January 2003, at <www.foreignaffairs.com/articles/56670/andrew-j-nathan/the-tiananmen-papers> (accessed 28 November 2018) 80; Haltern, U, "Book Review" 7 European Journal of International Law (1996) 135, 136; Max Planck Encyclopedia of Public International Law, Fox, G, Democracy, Right to, International Protection, March 2018, at <http://opil.ouplaw.com/view/10.1093/law:epil/9780199231690/law9780199231690-e773?prd=EPIL> (accessed 28 November 2018); Fox, G and Roth, B, "Democracy and International Law" 27 Review of International Studies (2001) 327, 338; Murphy, D, "Democratic Legitimacy and the Recognition of States and Governments" in Fox, G, and Roth, B, eds, Democratic Governance and International Law (Oxford University Press 2000), 123, 153.

97 d'Aspremont, J, "Legitimacy Of Governments In The Age Of Democracy" 38 New York University Journal of International Law and Politics (JILP) (2006) 881-882; d'Aspremont, J and De Brabandere, E, "The Complementary Faces Of Legitimacy In International Law: The Legitimacy Of Origin And The Legitimacy Of Exercise" 34 Fordham International Law Journal (2011) 190, 193.

98 Two such cases are the ones of the S. African and Rhodesia racist regimes and of the so- called Turkish Republic of Northern Cyprus. In both cases, jus cogens were violated. The apartheid governments and subsequently South Africa as a State passed from the level of 'normal' admission in the international community, to a gradual de-legitimisation in the UNGA from which they were eventually excluded from 
In relation to the issue of credentials and representation of Ethiopia in the League of Nations, as well as of Congo in 1960 and of Yemen in 1962 in the UN, a synthesis of criteria was adopted, including the compliance with international law and the dedication to world public order too. ${ }^{99}$

During the 90s in Liberia and in Sierra Leone, the ousting of incumbent presidents, despite the fact that they either controlled small parts of the territory - in the first case - or had fled the country - in the second case - did not prevent them from requesting foreign intervention. These requests were considered by the international community as valid and legitimate. 100

In the case of the coup in Haiti, Chapter VII was invoked in relation to the situation of internal legitimacy and constitutional order. In this context, the overthrow of President Aristide by a military coup was followed by widespread condemnation and the demand for Aristide's return to power. Both the GA and the SC adopted resolutions concerning the condition of democracy and human rights in Haiti. ${ }^{101}$ The denial of the military junta to comply led to the adoption of UN SC resolution 940, under Chapter VII, which, apart from authorising the use of force, referred to the ruling regime as the 'the illegal de facto regime'. 102

it, as well as by all UN bodies, in favour of antagonistic entities, namely the ANC and the Pan Africanist Congress of Azania, which were attributed the status of authentic representatives of the majority of the South African people. In the case of the so- called Turkish Republic of Northern Cyprus, the international community again has denied the recognition of the de facto created conditions on the ground due to the fact that it emerged out of a violation of jus cogens norms.

Stultz, N, "Evolution of the United Nations Anti-Apartheid Regime" 13(1) Human Rights Quarterly (1991) 1, 13-14; United Nations and the African National Congress, Reddy E. Partners in the Struggle against Apartheid, South African History Online at $<$ https://www.sahistory.org.za/archive/united-nations-andafrican-national-congress-partners-struggle-against-apartheid-e-s-reddy > (accessed 9 January 2019), 3-4; Lloyd, DO, "Succession, Secession, And State Membership In The United Nations" 26 New York University Journal of International Law \& Politics (1994) 761, 767-768; Talmon, S, "Who is a legitimate government in exile? Towards normative criteria for governmental legitimacy in international law" in Goodwin, G and Talmon, S, eds, The Reality of International Law. Essays in Honour of Ian Brownlie (Oxford University Press 1999), 499; Somewhat similar was the denial by the Allies of the legitimacy of newly established governments of collaborators of the Axis during World War II.

99 McDougal, $\mathrm{M}$ and Goodman, $\mathrm{R}$, "Chinese participation in the United Nations: the legal imperatives of a negotiated solution" Yale Law School Legal Scholarship Repository (1966) 694-695.

EJIL: Talk!, Vermeer, Z, Intervention with the Consent of a Deposed (but Legitimate) Government? Playing the Sierra Leone card, March 6, 2014, at <https://www.ejiltalk.org/intervention-with-the-consent-of-adeposed-but-legitimate-government-playing-the-sierra-leone-card/> (accessed 28 November 2018); However, in the same article it is mentioned that in both cases, ECOWAS and ECOMOG attempted to find complementary sources of legitimacy for their intervention in furtherance of the ousted presidents. Although that is true, it is also true that the international community did not take a hostile position toward the interventions.

101 Teson, F, "A Symposium on Reenvisioning The Security Council, Collective Humanitarian Intervention" 17 Michigan Journal of International Law (1996) 323, 355- 356;

UN Security Council, Haiti (16 June), 16 June 1993, (3238 ${ }^{\text {th }}$ meeting) S/RES/841.

102 Whilst this was obviously a reference to the domestic constitutional order, it was mainly on the basis of violations of international law endangering international peace and security that the potential of the use of force was invoked- although the connection between the two seemed to imply that the illegitimacy of the government should be and was assessed from an international law perspective, despite its de facto control of population and territory; UN Security Council, Authorization to form a multinational force under unified command and control to restore the legitimately elected President and authorities of the Government of Haiti and extension of the mandate of the UN Mission in Haiti, 31 July 1994, (3413 ${ }^{\text {th }}$ meeting) S/RES/940;

Tyagi, K, "The Concept of Humanitarian Intervention Revisited" 16 Michigan Journal of International Law (2005) 883, 898- 901. 
In Côte d'Ivoire, a similar position was adopted when, following the 2010 presidential elections, Laurent Gbagbo, who contested the official results, managed to get proclaimed as President of the country by the President of the Constitutional Council at the expense of the President-Elect Alassane Ouattara. The UN insisted on the recognition of Ouattara, imposing sanctions on Gbagbo's government, despite the fact that the government of the latter exercised effective control. ${ }^{103}$

In the coup d'état in Honduras and the overthrow of President Zelaya, the UN General Assembly - GA - in resolution 63/301, apart from the condemnation of the coup, called '...firmly and unequivocally upon States to recognise no Government other than that of the Constitutional President, Mr. José Manuel Zelaya Rosales', ${ }^{104}$ just as the Organization of American States - OAS. ${ }^{105}$ In a similar context, in Sierra Leone ${ }^{106}$ and in Cambodia in 1997107 the internal legitimacy criteria were considered as the dominant ones.

It seems that to some extent, in the immediate aftermath of coups against democratically elected governments, States, and the international community, are keen to deny legitimacy to governments that have emerged out of breaches of the constitutional order of States.

The most logical explanation for this approach is that military coups are profoundly distinct from whatever any popular uprising or rebellion could be, given that coups originate from within the State apparatus and certainly are in no position to claim that they implement internal self-determination better than a democratically elected government. This stance of the international community also implies the recognition of solidarity towards the people of a State and their rights, as an obligation of other States in the framework of international law.

However, this is not a solid approach. On the contrary, it is still 'vulnerable' to ad hoc and politically biased assessments. The international community, for example, was ready to legitimise and recognise the overthrow of Egyptian President Morsi by a military coup as well as the new government that was formed by the military junta. 108

A few decades before that, in Cambodia, during the controversy between Sihanouk's and Lon Nol's government, the UNGA recognised as legitimate the latter, which had been established by a coup, on the basis of the effectiveness criterion. ${ }^{109}$ It is

103 EJIL: Talk!, d'Aspremont, J, Duality of government in Côte d'Ivoire, January 4, 2011, at <http://www.ejiltalk.org/duality-of-government-in-cote-divoire/> (accessed 28 November 2018).

104 UN General Assembly, Situation in Honduras: democracy breakdown, 1 July 2009, (63rd session) A/RES/63/301.

105 The New York Times, Thompson, G and Lacey, M, O.A.S. Votes to Suspend Honduras over Coup, July 4 , 2009, at <https://www.nytimes.com/2009/07/05/world/americas/05honduras.html> (accessed 28 November 2018).

106 Similar is the case of Liberia in 1990. In both cases, a request to ECOWAS for action was sent, by the overthrown but otherwise legitimate presidents.

EJIL: Talk!, Vermeer, Z, Intervention with the Consent of a Deposed (but Legitimate) Government? Playing the Sierra Leone card, March 6, 2014, at <http://www.ejiltalk.org/intervention-with-the-consent-of-adeposed-but-legitimate-government-playing-the-sierra-leone-card/\#more-10479> (accessed 28 November 2018).

107 Downer, J, "Towards A Declaratory School Of Government Recognition" 46 Vanderbilt Journal of Transnational Law (2013) 581, 604-605.

108 See: US Department of State, Diplomacy in Action, Jen Psaki Spokesperson Daily Press Briefing Washington, DC, (26 July 2013).

B. Fernandez, The State Department and a tale of two coup-type things, (A1 Jazeera), 9 August 2013, at <https://www.aljazeera.com/indepth/opinion/2013/08/201388143913249526.html> (accessed 9 January 2019).

109 UN General Assembly, Restoration Of The Lawful Rights Of The Royal Government Of National Union Of Cambodia In The United Nations, 29 November 1974 (30 ${ }^{\text {th }}$ session) A/RES/3238; d'Aspremont, J, 
true that the UN organs as well as States' practice has failed to produce a uniform opinion or trend within the international community. ${ }^{110}$

The events of the Arab Spring, concerning government legitimacy and consensual intervention, blurred the lines even further both in legal and political terms. The cases of the Arab Spring do not mainly refer to military coups versus elected governments - apart from Egypt - but to the debate about what constitutes popular uprising and what rights such movements may claim in terms of representation of the State at the expense of the recognised government. Therefore, they also raised the issue of solidarity towards peoples in other States.

Libya and Syria pose two such paradigms. Although in the first, consensual intervention was not invoked, the attempted de-legitimisation of the then-recognised Qaddafi government and the partial-recognition of another entity instead, created a great deal of legal uncertainty.

During the internal war in Libya, the Libya Contact Group ${ }^{111}$ recognised as legitimate authority of Libya the National Transitional Council - NTC - instead of the Libyan government, on humanitarian grounds and despite the fact that NTC did no exercise effective control over Libyan territory. ${ }^{112}$

Dapo Akande in an accurate critique noted that 'Recognition of the Libyan NTC as the government of Libya when it did not have effective control of most of Libya was premature and therefore of dubious legality...Moreover premature recognition of governments coupled with assistance to that 'government' would set a very bad precedent indeed.' 113

And Professor Talmon asked: 'Through his actions, Colonel Qadhafi may 'have lost the legitimacy to govern' but has he also lost the competence to do so under international law? [...] International law does not distinguish between illegitimate regimes and lawful governments. 'Legitimacy' is a political concept and not a legal term of art. In fact, international law does not provide any criteria for defining and determining legitimacy.' 114

"Responsibility for Coups d' État in International Law" 18 Tulane Journal of International \& Comparative Law (2010) 451, 455- 456.

110 In such a framework, the US position during the proceedings of UNGA resolution 396/1950 referred to a synthesis of criteria incorporating the effectiveness of control over territory and population, the acceptance of responsibility for carrying out the obligations under UN Charter and the internal processes in the State; Annexes, Agenda Item 61, 9, United Nations General Assembly, Official Records (1950) A/AC.38/L.45.

111 Republic of Turkey, Ministry of Foreign Affairs' Libya Fourth Meeting of the Libya Contact Group Chair's Statement, (11 July 2015), at <http://www.mfa.gov.tr/fourth-meeting-of-the-libya-contact-group-chair_sstatement_-15-july-2011_-istanbul.en.mfa> (accessed 9 January 2019).

112 EJIL: Talk!, Akande, D, Recognition of Libyan National Transitional Council as Government of Libya, 23 July 2011, at <http://www.ejiltalk.org/recognition-of-libyan-national-transitional-council-as-government-oflibya/\#more-3607> (accessed 28 November 2018); EJIL: Talk!, Talmon, S, The Difference between Rhetoric and Reality: Why An Illegitimate Regime May Still Be A Government in the Eyes of International Law, 3 March 2011, at <http://www.ejiltalk.org/the-difference-between-rhetoric-and-reality-why-an-illegitimateregime-may-still-be-a-government-in-the-eyes-of-international-law/\#more-3101> (accessed 28 November 2018).

113 EJIL: Talk!, Akande, D, Would It Be Lawful For European (or other) States to Provide Arms to the Syrian Opposition?, 17 January 2013, at <http://www.ejiltalk.org/would-it-be-lawful-for-european-or-otherstates-to-provide-arms-to-the-syrian-opposition/\#more-7410> (accessed 28 November 2018).

114 Talmon, supra nt 112; To some extent that was the position, which was shared by the US administration itself, which distinguished between legality and legitimacy of the Libyan government; EJIL: Talk!, Akande, D, Which Entity is the Government of Libya and Why does it Matter?, 16 June 2011, at $<$ http://www.ejiltalk.org/which-entity-is-the-government-of-libya-and-why-does-it-matter/\#more- 
The events in Libya, for those advocating government legitimisation mainly on humanitarian grounds, were supposed to indicate a shift towards a criterion based on the respect of human rights and international law at the expense of the effective control of territory and population. Again, the idea was that a responsibility on behalf of the international community to manifest solidarity towards the people directly was prevalent - at least rhetorically.

However, what followed, with the total collapse of Libya as a State, rather proved such an attitude to be opportunistic; an arbitrary manipulation of legal norms, which bears grave dangers for the regional and international stability as well as for the welfare and the protection of human rights of the people concerned.115

Syria has also been a hard test of all legal theories. ${ }^{116}$ A bloc of States, mainly built around the US and its allies, attempted to de-legitimise the Syrian government and recognise the National Coalition for Syrian Revolutionary and Opposition Forces National Coalition - as the legitimate representative of the Syrian people in an attempt. This attempt fell short of a full recognition as government in exile not only because of legal reasons, but also following the developments on the battlefield, which gave the advantage to the Syrian government. 117

However, the US intervened in Syria partially on the basis of UNSC Res. 2249(2015), referring to the fight against IS and other terrorist organisations, but also during 2017 - in defense of the so-called Syrian Democratic Forces - SDF - a US-affiliated group - at least currently - of Kurds and Arabs as well as directly against the Syrian government following allegations of the use on its behalf of chemical weapons. While in initial stages of the US strikes against IS there could be some allegations of 'passive' or 'implied' consent on behalf of the Syrian Government it is by now obvious that the latter considers the actions taken by the US and its allies on Syrian territory as hostile acts of aggression, in violation of its sovereignty. ${ }^{118}$ Still though, the US without any solid legal justification maintains and expands its presence in Syria.

Russia and Syria's regional allies on the other hand invoked the invitation by the Syrian Government for their own intervention ${ }^{119}$ and denounced the US intervention as

3460> (accessed 28 November 2018).

115 Akande, supra nt 114; 'One further point to consider in all of this is whether the recognition of the NTC as the legitimate representative of the Libyan people points towards the creation of some sort of new status in international law... Something which is not quite a government (or perhaps even a kind of government), not quite a national liberation movement, not quite an insurgent. None of the States that has described the NTC as legitimate representative have stated explicitly that they regard this as a legal status...'

116 It will not be analysed here extensively, apart from some remarks that show the division of the international community over the issue of government legitimacy, mainly on the grounds of political speculations.

117 S. Talmon, Recognition of Opposition Groups as the Legitimate Representative of a People, (2013), 12, Chinese Journal of International Law, 219, at p. 220, BBC News, Russia anger at Syrian Arab League opposition seat, 27 March 2013, at <www.bbc.co.uk/news/world-middle-east-21953423> (accessed 28 November 2018); Official Journal of the European Union, Council Decision 2013/186/CFSP of 22 April 2013, 22 April 2013, at <eur-lex.europa.eu/LexUriServ/LexUriServ.do?uri=OJ:L:2013:111:0101:0102:EN:PDF> (accessed 28 November 2018); Official Journal of the European Union, Council Decision 2013/103/CFSP of 28 February 2013, 28 February 2013, at <eur-lex.europa.eu/LexUriServ/LexUriServ.do? uri=OJ:L:2013:058:0008:0008:EN:PDF> (accessed 28 November 2018); Deutsche Welle, EU Boosts Status of Syria's National Coalition, 11 December 2012, at <www.dw.de/eu-boosts-status-of-syriasnational-coalition/a-16443081> (accessed 28 November 2018).

118 EJIL: Talk!, Van Steenberghe, R, From Passive Consent to Self-Defence after the Syrian Protest against the USled Coalition, October 23, 2015, at <https://www.ejiltalk.org/13758-2/> (accessed 28 November 2018).

119 Lucas, S, The effects of Russian intervention in the Syria Crisis (GSDRC, University of Birmingham, 2015 ), 1. 
illegitimate. While the US and its allies have criticised the Russian intervention up to the extent that it has been critical for the survival of the Syrian Government, they have not directly denied its legitimacy. Their position towards the Syrian Government has not reached the level of its complete de-legitimisation. Again, solidarity among States as well as towards parts of the Syrian people were invoked by the different intervening parts.

In Ukraine, following the overthrow of President Yanukovych, the majority of the international community recognised as legitimate the de facto government of Ukraine, ${ }^{120}$ although the vote for his removal by the Ukrainian Parliament fell short of the constitutional provisions. ${ }^{121}$

Ousted President Yanukovych asked for Russian intervention, a request which in principle should amount to a sound and valid justification for foreign intervention. ${ }^{122}$ Both the Russian ambassador in the UNSC as well as the Russian President invoked this letter of consent from the President of Ukraine as a legitimate provision of consent for intervention. ${ }^{123}$

Yanukovych's consent was rejected as potential basis for Russian intervention by many members of the international community, because he was not exercising effective control over Ukrainian territory and population. ${ }^{124}$ Russia maintained that it considered it as a legitimate request from the legitimate - at that point - president, ${ }^{125}$ although it never accepted that it intervened in E. Ukraine and therefore it did not invoke it. ${ }^{126}$

Behind these inconsistent practices lie obviously geopolitical and national security interests, which prevail over legal clarity. One could also trace - in indirectly legal and moral terms - a differentiation on the basis of whether the entity challenging government authority resembles to a popular uprising or rebellion turning against an authoritarian government and therefore bears the potential for genuine expression of popular will or not. In the primary case, a part of the international community is keen to recognise and legitimise the domestic transformations within the State as legitimate and seems to be finding it reasonable and legitimate to show its solidarity towards the people directly.

Things supposedly are simpler in cases where a government has to deal with nonState, terrorist actors, such as the Islamic State - IS - or Al Qaeda and affiliated groups. The French intervention in Mali under UNSC Resolution 2085 following the invitation of

120 The Guardian, Agreement on the Settlement of Crisis in Ukraine (Kyiv, 21 February 2014), at $<$ www.theguardian.com/world/2014/feb/21/agreement-on-the-settlement-of-crisis-in-ukraine-fulltext> (accessed 9 January 2019).

121 Vermeer, supra nt 100.

122 BBC News, Ukraine's Yanukovych asked for troops, Russia tells UN, 4 March 2014, at $<$ http://www.bbc.com/news/world-europe-26427848> (accessed 28 November 2018).

123 Putin, V, Vladimir Putin answered journalists' questions on the situation in Ukraine, President of Russia, 14 March 2014, at <en.kremlin.ru/events/president/news/20366> (accessed 28 November 2018).

124 EJIL: Talk!, Wisehart, D, The Crisis in Ukraine and the Prohibition of the Use of Force: A Legal Basis for Russia's Intervention?, 4 March 4 2014, at <http://www.ejiltalk.org/the-crisis-in-ukraine-and-theprohibition-of-the-use-of-force-a-legal-basis-for-russias-intervention/\#more-10459> (accessed 28 November 2018); Allison, R, "Russian 'Deniable' Intervention in Ukraine: How and Why Russia Broke the Rules" 90(6) International Affairs (2014) 1255, 1264.

125 Churkin, V, at Security Council 7125th Meeting (3 March 2014), Assistant Secretary-General for Political Affairs Updates Security Council as It Holds Second Meeting on Ukraine in Three Days Security Council 7125th Meeting (PM), at <https://www.un.org/press/en/2014/sc11305.doc.htm> (accessed 9 January 2019).

It is interesting to note here that the US declined Yanukovych's consent -at least partially- on the basis of the unconstitutionality of his act; Allison, supra nt 124, 1264-1265.

126 Interview with Radio Europe 1 and TF1 TV channel, 4 June 2014, Russian Presidential Website and BBC Monitoring Online (4 June 2014), at <https://www.youtube.com/watch?v=MrFqCF0dbgM> (accessed 9 January 2019). 
the government of Mali, ${ }^{127}$ as well as the participation of coalition forces on the side of the Iraqi Government in the course of the fight against IS in Iraq pose two such examples.

In addition, there are cases where consent is an additional basis of the legitimacy of the intervention, together with the invocation of self-defense, such as that of Kenyan intervention in Somalia in 2011 against Al-Shabaab. The most 'convenient' justification was the consent of the Somali Government although Kenya invoked implicitly its right to self-defense against Al-Shabaab. The Somali position was somewhat ambiguous, but still its most reasonable interpretation is that the government of Somalia consented to the intervention. ${ }^{128}$

A similar case is the prolonged US intervention in Afghanistan. Whilst initially the US invoked the right to self-defense in order to invade Afghanistan and overthrow the de facto Taliban regime following the 9/11 attacks on the basis of the ties between the Taliban and $\mathrm{Al}$ Qaeda ${ }^{129}$ and although the UNSC resolutions 1368 and 1373 are widely considered as authorising US use of force at the time, ${ }^{130}$ the continuous presence of US forces - apart from those of the international security force, ISAF - is based at large on the consent of the Afghani Government. 131

Although the Afghani Government was imposed and is kept in power mainly because of the US intervention and despite the fact that it does not exercise full control over the territory and the population, its endorsement by the international community as the legitimate one and the nature of the organisation fighting against are two main reasons for attributing to it the right to consent to intervention. 132

In practice though, even under such conditions quite often it becomes complicated enough to reach a uniform solution. ${ }^{133}$ The lack of unanimous definition of terrorist organisations, the complicated conditions on the ground and the contradictory State interests prove that even seemingly obvious legal trends and norms are quite often too

127 EJIL: Talk!, Christakis, T and Bannelier, K, French Military Intervention in Mali: It's Legal but... Why? Part II: Consent and UNSC Authorisation, 25 January 2013, at <https://www.ejiltalk.org/french-militaryintervention-in-mali-its-legal-but-why-part-2-consent-and-unsc-authorisation/> (accessed 28 November 2018).

128 Lieblich, supra nt 55, 16.

129 Bush, GW, Address to the Nation Announcing Strikes against Al Qaida Training Camps and Taliban Military Installations in Afghanistan, 7 October 2001, 2 PUB Papers, 1201-1202; Bush, GW, President's Radio Address, 13 October 2001, 2 PUB Papers, 1235- 1236;

Bush, GW, Remarks on Signing the Afghan Women and Children Relief Act of 2001, 12 December 2001, 2 PUB Papers, 1506- 1507; On 7 October 2001, the US informed the UN Security Council that it was exercising '...its inherent right of individual and collective self-defense...', by actions '... against Al Qaeda terrorist training camps and military installations of the Taliban regime in Afghanistan...'; UN Security Council, Letter dated 7 October 2001 from the Permanent Representative of the United States of America to the United Nations addressed to the President of the Security Council, 7 October 2011, UN DOC S/2001/946.

130 UN Security Council, Condemnation of 11 September attacks against United States, 12 September 2001, (4370th meeting) S/RES/1368: ' ...the inherent right of individual or collective self-defense in accordance with the Charter...' In the first paragraph, the resolution 'Unequivocally condemns in the strongest terms the horrifying terrorist attacks which took place on 11 September 2001 in New York, Washington, D.C. and Pennsylvania and regards such acts, like any act of international terrorism, as a threat to international peace and security.' The Resolution also reaffirmed '...that such acts, like any act of international terrorism, constitute a threat to international peace and security...', '... the inherent right of individual or collective self-defence as recognised by the Charter of the United Nations as reiterated in resolution 1368 (2001) ...' and the '...the need to combat by all means, in accordance with the Charter of the United Nations, threats to international peace and security caused by terrorist acts...'.

131 Lieblich, supra nt 55, 17-18.

132 Ibid., 18-19.

133 Even more, the endless Afghani war, if we take into account the US support back in the 80s, towards what came to be the Taliban. 
complicated to implement.

Parenthetically, the case of Afghanistan, as well as the case of Iraq in relation to the fight against IS, could give rise to the question of the genuineness of the consent, since both governments are the outcome of US actions and need - or at least needed - US help in order to survive. Therefore, the origins and the dependency of the two governments raise the issue of whether they were in fact coerced to consent.

It is true that in such situations of inequality and dependency, the actual limits between coercion and genuine consent are blurred. While such an argument is interesting, it bears the danger that almost all cases of consent provided by weaker States to significantly more powerful States would be considered as null and void. Normatively speaking, such a consent can be considered as valid since the international community has recognised the government as lawful, meaning, therefore, that in terms of international law it falls under the equal sovereignty provision of the UN Charter.

Here, the reference to the principle of solidarity can become a test, which provides insightful understanding. More specifically, the intervening State must take into account that it needs to combine solidarity towards the government of the State with solidarity towards the people - or at least not to deteriorate the position of the latter. A balanced approach therefore, between the two sides of solidarity provides us with a normative, interpretative tool on the issue.

A similar case, in terms of the genuineness of the consent, is that of the Syrian intervention and presence in Lebanon for almost 3 decades, from 1976 to 2005. In this case, whilst the consent of the Lebanese government had been offered and was re-affirmed, the international community eventually demanded the withdrawal of all foreign troops, treating the Lebanese consent as more or less the outcome of coercion or at least as nonsatisfactory under international law to provide legitimacy. ${ }^{134}$

The genuineness of the consent coincides emphatically in this case, with the solidarity criterion. It is not only the typical or even substantial will of the government that matters but also the impact of the intervention on the people and the life of the State in general. Therefore, again, inter-State solidarity must be assessed continuously with solidarity to the people.

Apart from its significance regarding the genuineness of the consent in principle, the case of Syrian presence in Lebanon is important because it shows that the act of consent might be singular, but its assessment is continuous. In addition, it showed that the fact that consensual intervention is a form of bilateral agreement does not exclude the UNSC as an organ to which international peace and security is entrusted.

Therefore, a once valid act of consent might be de-legitimised in the future for a variety of reasons. As such can be considered the case of the Saudi-led intervention in Yemen. Even if the consent of the ousted by the Houthis' uprising, president Hadi is to be considered as in principle lawful, on the basis of the internal constitutional formation of Yemen and of UN SC resolution 2216(2015) 135 - which is not without contrary arguments - the scope of the consent and the specific means of the intervention have de-legitimised

${ }_{134}$ Lieblich, supra nt 55, 18-19; UN Security Council, Security Council Declares Support For Free, Fair Presidential Election In Lebanon; Calls For Withdrawal Of Foreign Forces There, 2 September 2004, (5028 ${ }^{\text {th }}$ Meeting) SC81/81, at <https://www.un.org/press/en/2004/sc8181.doc.htm> (accessed 9 January 2019).

135 UN Security Council, Security Council Demands End to Yemen Violence, Adopting Resolution 2216 (2015), with Russian Federation Abstaining, 14 April 2015, (7426 ${ }^{\text {th }}$ meeting) S/RES/2216, at $<$ https://www.un.org/press/en/2015/sc11859.doc.htm> (accessed 9 January 2019). 
it,136 exactly on the basis that the right of a government to invite an intervention, as well as of the third State to respond positively are not unconditional. The scope of the consent as well as the means of the intervention co-determine their legitimacy, in the basis of the need to balance between the two aspects of solidarity.

The variety of cases and State approaches indicate that the interpretation of law in relation to government legitimacy in situations of contested authority necessitate answers, which must include a combination of criteria, keeping in mind that an ad hoc assessment is inevitable and critical. 137

The existence of the government as a matter of the control of territory and population for a sufficient period of time constitutes undoubtedly the primary criterion of legitimacy. When, due to the emergence of antagonistic entities, which control extended part of the territory and of the population, ${ }^{138}$ the governmental capacity and its primary source of legitimacy are contested, ${ }^{139}$ an assessment including several criteria must be adopted: what is the extent of government loss of control over the State; 140 why government

136 Lawfare, Deeks, A, International Legal Justification for the Yemen Intervention: Blink and Miss It, Lawfare, 30 March 2015, at <www.lawfareblog.com/international-legal-justification-yemen-intervention-blink-andmiss-it> (accessed 28 November 2018); IRIN News, Dyke, J, Is the Saudi war on Yemen legal?, 3 April 2015, at <www.irinnews.org/analysis/2015/04/03/saudi-war-yemen-legal> (accessed 28 November 2018).

137 Roth, B, "Governmental Illegitimacy Revisited: 'PRO-DEMOCRATIC' Armed Intervention In The Post-Bipolar World" 3 Transnational Law \& Contemporary Problems (1994) 481, 495; It must be mentioned here that the history of the UN itself indicates not an absolute persistence on the objective criteria. According to Brad Roth: 'The history of the United Nations has known eight significant credentials contests involving China, Hungary, Congo (Leopoldville), Yemen, Cambodia (1973-74 and post-1978), South Africa, and Israel. The de facto regime was denied credentials in the cases of China (1950-71), Hungary (1957-63), Cambodia (post-1978) and South Africa (1974), and narrowly prevailed in the case of Cambodia in 1973-74.'

138 The most suitable legal term would be that it must be questioned 'beyond reasonable doubt'.

139 Obviously, the terms 'legitimate representative' and 'legitimate government' are not identical. The analysis here focuses on the issue of government. The reference to the attribution of the status of 'legitimate representative' is made here only parenthetically, in the sense of a first step leading to the second and most important one; Dinstein, Y, War, Aggression and Self-Defence (4 ed, Cambridge University Press 2005) 116; While it is less intervening compared to regime change intervention, still it bears significant legal consequences. For example, it raises the question of which entity possesses the authority to provide consent for an outside intervention; Lieblich, E, "Intervention and Consent: Consensual Forcible Interventions in Internal Armed Conflicts as International Agreements" 29 Boston University International Law Journal (2011) 337,357-359; Auron, D, "The Derecognition Approach: Government Illegality, Recognition, And Non-Violent Regime Change" 45 George Washington International Law Review (2013) 443, 484-485.

140 Farer, TJ, "Panama: Beyond The Charter Paradigm" 84 American Journal of International Law (1990) 503, 510-511; Governments that control the capital of the State and extended parts of the territory, without facing imminent danger of collapse, at least in some instances, are comprehended as possessing internal legitimacy. A contrary, and not totally unjustified position, though, is that a contested government, even in partial control, should share its power with the opposition, given that it fails to control the whole of territory and population; Wippman, D, "Treaty- Based Intervention: Who Can Say No?" 62 University of Chicago Law Review (1995) 605, 627- 628; Wippman, D, "Change and Continuity in Legal Justifications for Military Intervention in Internal Conflict" 27 Columbia Human Rights Law Review (1996) 435, 435- 444; Walzer, M, "The Moral Standing of States: A Response to Four Critics" 9 Philosophy \& Public Affairs (1980) 209, 216-218; Delahunty, RJ and Yoo, J, "Statehood and the Third Geneva Convention" 46 Virginia Journal of International Law (2005) 131, 138; Fox, G, "Self-Determination In the Post-Cold War Era: A New Internal Focus?" 16 Michigan Journal of International Law (1995) 733, 738; Buchheit, L, Secession: The Legitimacy of Self-Determination (Yale University Press 1978), 9-11; Thornberry, P, "The Democratic or Internal Aspect of Self-Determination", in Tomuschat, C, ed, Modern Law of SelfDetermination (Martinus Nijhoff 1993) 102, 124-125; Grant, T, "Between Diversity And Disorder: A 
control has been lost, ${ }^{141}$ compliance or not with the constitutional formation and democratic standards; ${ }^{142}$ fulfillment of internal self-determination standards; ${ }^{143}$ stable presence of this form of government within the domestic constitutional history of the State. ${ }^{144}$

It would be convenient enough to be able to draw an equation determining the exact relationship among these three types of criteria; regrettably that is impossible. It is logical, though, to suggest a combined assessment of legitimacy including all types of criteria. The entity which meets most of the standards in all categories should bear legitimacy. Obviously, these guidelines come down to an ad hoc examination. The most that anyone can expect from an international lawyer or the international community is sincerity in the implementation of these criteria, since no pre-determined solutions can be provided.

Eventually, the principle of solidarity can offer guidance: in the end, the question must be whether the invited intervention, under the light of the aforementioned criteria, establishes a balanced approach between solidarity among States and solidarity towards the people, keeping in mind that on the one hand, State sovereignty constitutes a means for the end, which is the welfare of the people and on other hand that solidarity to the people must not come to constitute a pretext for regime change interventions, which eventually deteriorate the position of the people at State, even more.

\section{Conclusion}

The article attempted to incorporate into the debate about consensual intervention the principle of solidarity. From such a perspective it examined the nature of solidarity exactly as a fundamental principle of international law which can be identified as the driving force behind the collective security system.

The lawfulness of consensual intervention is assessed through a combination of paragons from both sides - i.e. both the inviting part and the intervening. These paragons include the situation on the ground as well as the compliance with internal and international law. Behind these limitations lies the solidarity principle which obliges both the consenting government and the intervening State, to take into account solidarity among States, as well as solidarity towards the people.

This approach becomes even more critical in cases of States of contested government authority, not only for the inviting but also from the intervening forces as well, since it is their responsibility too, to assess the legitimacy of the consent they are being given. They need to revisit these criteria, through the perspective of the two aspects solidarity, towards States and the people. In this sense, the principle of solidarity eventually determines the legitimacy of the intervention. The intervening State in the framework both of jus ad bellum and jus in bello needs to assess the responsibility to manifest solidarity towards both the State and the people.

Review Of Jorri C. Duursma, Fragmentation And The International Relations Of Micro-States: SelfDetermination And Statehood" 12 American University Journal of International Law and Policy (1997) 629, 637.

141 There are obvious political differences, which may have legal implications, on the basis of whether the cause for the loss of control is a military coup or a popular uprising.

142 Crawford, J, The Creation of States in International Law ( $2^{\text {nd }}$ ed, Oxford University Press 2007), 57

143 Hamid, R, "What is the PLO?" 4(4) Journal of Palestine Studies (1975) 90, 90-109; Such a case of implementation of self-determination without State authority, although in the course of a nationalliberation and self- determination struggle, is the one of the PLO.

144 Lee, TW, "Point-Counterpoint: The International Legal Status of Taiwan: The International Legal Status of the Republic of China on Taiwan" 1 UCLA Journal of International Law \& Foreign Affairs (1997) 351, 385. 
The international community has found it hard to reach unanimous ground on how to deal with such situations, mainly because of their profound political impact, as well as because of contradictory interpretations of international law. The principle of solidarity is omnipresent in this debate through the variety of international law provisions. A direct reference to solidarity as a criterion is necessary so that an elaborate assessment of the conditions on the ground can be achieved. 